\title{
ПРАВОВАЯ ПОЛИТИКА РОССИЙСКОЙ ФЕДЕРАЦИИ В СФЕРЕ ЮРИДИЧЕСКОГО ОБРАЗОВАНИЯ
}

\author{
(c) 2021 Шпак Анастасия Александровна \\ магистрант Юридической школы ДВФУ, \\ 40.04.01 «Юриспруденция» программа «Юрист в сфере публичного права» \\ Дальневосточный федеральный университет, Россия, Владивосток \\ E-mail: anastasiya-shpak98@mail.ru \\ (C) 2021 Шахова Анастасия Максимовна \\ магистрант Юридической школы ДВФУ, \\ 40.04.01 «Юриспруденция» программа «Юрист в сфере публичного права» \\ Дальневосточный федеральный университет, Россия, Владивосток \\ E-mail: nastiaaleshk@mail.ru

\section{(c) 2021 Шахов Никита Владимирович} \\ магистрант Юридической школы ДВФУ, \\ 40.04.01 «Юриспруденция» программа «Юрист в сфере публичного права» \\ Дальневосточный федеральный университет, Россия, Владивосток \\ E-mail: shahovnik@mail.ru
}

\begin{abstract}
Актуальность исследуемой темы можно показать на примере замкнутого круга: правовую политику создают юристы, их разработки влияют на формирование новых поколений юристов, которые создадут правовую политику будущего. На основе анализа нормативного материала автор делает выводы о наличии недостатков в правовой политике РФ в сфере юридического образования, в том числе о ее нестабильности и отсутствии фундаментальных научно обоснованных программных документов.
\end{abstract}

Ключевые слова: государственная политика, правовая политика, образовательная политика, высшее образование, юридическое образование, юриспруденция.

Профессия юриста является достаточно древней и сложной, но, тем не менее, остается востребованной. Как и любая другая сфера деятельности, она требует наличия определенных знаний, умений, навыков, которые формируются и развиваются в процессе образования. В соответствии с законодательством РФ образование - это, с одной стороны, единый целенаправленный процесс воспитания и обучения, с другой - совокупность приобретаемых знаний, умений, навыков, ценностных установок, опыта деятельности и компетенции определенных объема и сложности [4].

Строго юридическим образованием следует считать образование, получаемое по соответствующим, специально разработанным, образовательным программам. Тем не менее, люди (даже не связывающие свою судьбу с правовой сферой) могут получать знания по юриспруденции в течение всей жизни. Значение качества таких знаний также нельзя недооценивать.
Так или иначе, специально полученное юридическое образование важно и для отдельной личности, решившей его получить, и для всего общества и государства. Наличие диплома о высшем юридическом образовании дает индивидууму доступ к ряду должностей, возможность заниматься специфической профессиональной деятельностью, для которой не подходит квалификация в иных сферах, а также формирует разносторонне развитую личность, ориентированную на правовые ценности. Государству и обществу образованность граждан в области права дает высокий уровень правосознания граждан, высокий уровень соблюдения законности, снижение количества правонарушений, наличие квалифицированных специалистов, качество правотворческой и правоприменительной деятельности, признание России на мировом уровне как правового государства, обладающего достаточными ресурсами для поддержания правопорядка, защиты прав и свобод человека и 
гражданина.

Ввиду важности юридического образования граждан для государства обоснованно ожидать, что оно обеспечит наличие определенной программы, направленной на поддержание и совершенствование данной сферы - а именно будет проводить узконаправленную государственную политику.

В свою очередь правовая политика является частью общей государственной политики. Она, по мнению А.В.Малько, представляет собой научно обоснованную, последовательную и системную деятельность государственных органов и институтов гражданского общества по созданию эффективного механизма правового регулирования и цивилизованному использованию юридических средств для достижения целей наиболее полного обеспечения прав и свобод человека и гражданина, формирования правовой государственности, высокого уровня правовой жизни общества и личности [2, С. 55]. Очевидно, ключевым словом является «деятельность» (активное поведение, динамика).

Таким образом, можно сделать вывод, что правовая политика в сфере юридического образования - это системная деятельность государственных органов по правотворчеству и правоприменению, осуществляемая в целях обеспечения права человека по получение качественного юридического образования. Так как она является частью общей образовательной политики России, для нее свойственны общие основы, принципы, методы, способы и инструменты реализации. Тем не менее, вполне обоснованно ожидать наличия отдельных нормативных положений, учитывающих специфику юридического образования.

Основополагающим программным документом, касающимся этого вида образования в России, являются Основы государственной политики Российской Федерации в сфере развития правовой грамотности и правосознания граждан [9], утвержденные в 2011 году. К сожалению, именно юридическому образованию в этом документе посвящен сравнительно небольшой раздел.

Единственный пункт этого раздела, содержащий формулировку «юридическое образование», указывает на необходимость прогнозирования потребности в специалистах-юристах, включающего практико-ориентированную разработку перечня специализаций юридической подго- товки. Иные направления деятельности можно описать как: 1) распространение правового образования на все уровни образования (а также весь период жизни человека - учитывая распространение программ дополнительного профессионального образования для взрослых), 2) повышение уровня правовой грамотности и подготовки лиц, чья профессиональная деятельность связана с правом, 3) распространение сети юридических клиник. Не смотря на скудность формулировок, Основы являются единственным актом, действительно говорящим о юридическом образовании, хотя и не решающим всех его проблем.

Также общая политика РФ в сфере образования нашла выражение в ряде актов Президента и Правительства. Интересно, что первые (по времени принятия) два документа прямо говорили о юридическом образовании. Так, согласно указу Президента 2012 г. Правительству РФ надлежало представить предложения по проведению общественно-профессиональной аккредитации образовательных программ высшего профессионального образования, в первую очередь по направлениям подготовки (специальностям) в области юриспруденции [3]. Распоряжение Правительства 2013 г. говорило о первоочередной необходимости проведения в 2012-2014 годах аудита всех образовательных программ высшего образования по юриспруденции [5]. При этом, последующие документы (более поздние по времени принятия) не содержат ни единого упоминания о юридическом образовании, юриспруденции, правовом образовании.

Тем не менее, можно положительно охарактеризовать наличие современного национального проекта «Образование» [10]. Согласно данному документу в РФ создаются нормативноправовые, финансово-экономические, организационно-управленческие, информационноаналитические, кадровые и научные условия для реализации потенциала граждан в социальноэкономической сфере, внедрения технологии «социального лифта» и проведения профессиональных конкурсов - в том числе по направлению развития правового просвещения граждан.

Таким образом, не смотря на существование перечисленных документов, становится понятно, что, к сожалению, общий программный акт по развитию юридического образования в России отсутствует - хотя правила, по которым существует современное государство, создают 
именно юристы.

Специализированным документом, направленным на регулирование порядка предоставления образования по конкретной специальности является федеральный государственный стандарт (далее - ФГОС). Государство выражает в таких документах свои требования к структуре образовательной программы (в том числе, перечень дисциплин, реализацию которых обязана обеспечить образовательная организация), к результатам освоения программы (зачастую оценочные категории, как, например, способность к осуществлению социального взаимодействия), к условиям реализации программы (к материально-техническому, кадровому и иным видам обеспечения).

При этом, ФГОС постоянно совершенствуются: за последние 10 лет ФГОС для юристовбакалавров был переиздан три раза. Здесь можно усмотреть еще одну проблему механизма регулирования образования (не только юридического) в России: количество нормативных актов возрастает, а в уже существующие постоянно вносятся изменения. Нестабильность правового регулирования не влияет положительно на состояние регулируемой сферы в любом случае.

Следует не принимать новые нормативноправовые акты, а совершенствовать уже имеющиеся - соблюдая требование о научнообоснованном подходе к нововведениям и меру в количестве и частоте изменений. Также вредно слишком конкретизировать требования к юридическому образованию, иначе это низведет современное право до уровня древних казуальных норм. Представляется, что именно уровень документов общегосударственной правовой политики является подходящим для разрешения проблем юридического образования.

Еще одну область для дискуссий, напрямую связанную с изменением нормативного регулирования, создало присоединение Российской Федерации к Болонскому соглашению 1999 г. [1]. С момента введения так называемой «Болонской» системы образования до настоящего времени не только существует двухуровневое высшее образование (при параллельном наличии специалитета), а также получить степень магистра юриспруденции может лицо, имеющее любое образование предыдущего уровня.

Это отражается и в документах о поступлении в отдельные образовательные организации. Так, Дальневосточный федеральный университет определяет, что «к освоению программ магистратуры допускаются лица, имеющие образование соответствующего уровня, подтвержденное документом о высшем образовании и о квалификации» [11] (без указания на соответствующую специальность). Также в программе вступительных испытаний для лиц, поступающих в 2021 году в магистратуру по направлению «Юрист в сфере публичного права» учитывается в качестве составляющей портфолио наличие диплома бакалавра (или специалиста) по другим (не юридическим) направлениям подготовки. Хотя, следует отметить, что вес (в баллах) таких дипломов несколько ниже, чем аналогичных документов о юридическом образовании [12].

Продолжая разговор об уровнях юридического образования, следует вспомнить, что целью Болонского соглашения является подготовка мобильных специалистов, способных работать не только на территории своего государства. В отношении российского юридического образования эта цель во многом потеряна: согласно ФГОС для бакалавров обязательными являются по большей части предметы не универсального характера. Естественно, что изучая уголовное, гражданское, административное, налоговое право, право социального обеспечения и др., студент будет постигать отечественное право. В том числе задачи профессиональной деятельности, к осуществлению которых должен быть готов выпускник-бакалавр (нормотворческого, правоприменительного, правоохранительного и экспертно-консультационного типа) подразумевают под собой национальную специфику. Поэтому на данный момент представить организацию массового процесса подготовки юристов-универсалов сложно, для этого не создаются соответствующие условия.

Наконец, в качестве еще одной проблемы можно назвать непоследовательность государственно-правовой политики по поддержке абитуриентов и студентов-юристов. Поддержка абитуриентов и уже обучающихся граждан выражается, во-первых, в количестве бюджетных мест, устанавливаемых уполномоченным государственным органом на определенный учебный год. Официальные данные говорят о том, что количество бюджетных мест на бакалавриат, специалитет, магистратуру и аспирантуру только в планах на 2022 г. достигает предыдущих показателей после спада, произошедшего в период с 2017 г. по 2019 г. [6].

Кроме того, с помощью правовых инструментов выражается и материальная поддержка 
со стороны государства для лиц, получающих юридическое образование. Так, в 2002 г. указом Президента и постановлением Правительства была учреждена стипендия имени А. А. Собчака [7] для лиц, получающих юридическое образование, в 2011 г.- стипендия В.А.Туманова [8]. Размер первой из названных поощрительных выплат составляет всего 700 рублей в месяц, второй - 2000 и 10000 в месяц для студентов и аспирантов соответственно.

Таким образом, можно сделать, возможно, неожиданный, но наиболее верный, на взгляд автора, вывод о двойственности правовой политики отечественного государства в сфере юридического образования. С одной стороны, государство издает множество нормативно- правовых актов, затрагивающих сферу образования. С другой стороны - нельзя сказать, что правовая политика в сфере юридического образования сегодня достаточно разработана, конкретизирована и действительно направлена на обеспечение и повышение его качества и поддержку лиц, его получающих. В этой ситуации общее, рамочное, диспозитивное регулирование (скорее провозглашение направлений, по которым должно развиваться и идеалов, которым должно соответствовать юридическое образование), учитывающее актуальные проблемы и тенденции юридического образования, видится достойным выходом из вакуума, сформировавшегося вокруг современного юридического образования.

\section{Библиографический список}

1. Декларация о создании общеевропейского пространства высшего образования (принята в г. Болонье 19.06.1999) - Официальный сайт Болонского процесса. URL: http://www.ehea.info/page-ministerialconference-bologna-1999 - Текст: электронный.

2. Малько А.В. Правовая политика в современном обществе: общетеоретический и сравнительный анализ // Право и государство. 2018. № 3-4 (80-81). С. 54-64.

3. О мерах по реализации государственной политики в области образования и науки: указ Президента РФ от 7 мая 2012 г. № 599. - Доступ из СПС «КонсультантПлюс».- Текст: электронный.

4. Об образовании в Российской Федерации: Федер. закон от 29.12.2012 № 273-ФЗ (с изм. и доп., вступ. в силу с 13.07.2021).- Доступ из СПС «КонсультантПлюс».- Текст: электронный.

5. Об утверждении государственной программы РФ «Развитие образования» на 2013-2020 годы»: распоряжение Правительства РФ от 15.05.2013 № 792-р.- Доступ из СПС «КонсультантПлюс».- Текст: электронный.

6. Об утверждении общих объемов контрольных цифр приема по специальностям и направлениям подготовки и (или) укрупненным группам специальностей и направлений подготовки для обучения по образовательным программам высшего образования за счет бюджетных ассигнований федерального бюджета на 2022/23 учебный год: приказ Минобрнауки России от 11.01.2021 № 1.- Доступ из СПС «КонсультантПлюс».- Текст: электронный. Об утверждении федерального государственного образовательного стандарта высшего образования - бакалавриат по направлению подготовки 40.03.01 Юриспруденция: приказ Министерства науки и высшего образования РФ от 13 августа 2020 г. № 1011.

7. Об учреждении стипендий имени А.А. Собчака: постановление Правительства РФ от 22.05.2002 № $329-$ Доступ из СПС «КонсультантПлюс».-Текст: электронный.

8. Об учреждении стипендий имени В.А. Туманова для студентов образовательных организаций высшего образования и аспирантов образовательных организаций высшего образования, организаций дополнительного профессионального образования и научных организаций: постановление Правительства РФ от 21.03.2012 № 214 (ред. от 28.09.2018) - Доступ из СПС «КонсультантПлюс».- Текст: электронный.

9. Основы государственной политики Российской Федерации в сфере развития правовой грамотности и правосознания граждан (утв. Президентом РФ 28.04.2011 № Пр-1168).- Доступ из СПС «КонсультантПлюс».Текст: электронный.

10. Паспорт национального проекта «Образование» (утв. президиумом Совета при Президенте РФ по стратегическому развитию и национальным проектам, протокол от 24.12.2018 № 16).- Доступ из СПС «КонсультантПлюс».- Текст: электронный.

11. Правила приёма на обучение по программам магистратуры в ДВФУ на 2021/22 учебный год. - URL: https:// www.dvfu.ru/admission/pk2021.m/pp.m.2021.php - Текст: электронный.

12. Программа вступительных испытаний для поступления на направления подготовки магистратуры 40.04 .01 «Юриспруденция» программа «Юрист в сфере публичного права».- URL: https://www.dvfu.ru/admission/ program-bs/b/ - Текст: электронный. 